\title{
Molecular analysis of a Leptospira borgpetersenii gene encoding an endoflagellar subunit protein
}

\author{
Marina Mitchison, Julian I. Rood, Solly Faine and Ben AdleR* \\ Department of Microbiology, Monash University, Clayton, Victoria 3168, Australia
}

(Received 21 January 1991; revised 15 March 1991; accepted 26 March 1991)

\begin{abstract}
A flagellin gene, flaB, from Leptospira borgpetersenii (formerly $L$. interrogans) serovar hardjo was cloned and expressed in Escherichia coli. Expression of the $32 \mathrm{kDa}$ FlaB protein was dependent upon the lac $Z$ promoter from pUC18. Nucleotide sequence data showed an open reading frame encoding 283 amino acid residues, corresponding to a protein of molecular mass $31.3 \mathrm{kDa}$. The $\mathrm{G}+\mathrm{C}$ content of the $f l a B$ gene was $54.7 \mathrm{~mol} \%$. Comparison of the deduced FlaB amino acid sequence with flagellins from other bacteria revealed a high level of identity with the Treponema pallidum FlaB proteins.
\end{abstract}

\section{Introduction}

Motility in leptospires is dependent on the presence of endoflagella located between the protoplasmic cylinder and the outer membrane sheath (Smibert, 1973). In these organisms there are two flagella inserted subterminally into the protoplasmic cylinder at each pole of the cell (Chang \& Faine, 1970). Like many other flagella studied, leptospiral flagella consist of a basal body, hook and filament (Smibert, 1973). Using Western blotting techniques, flagellar proteins have been identified in both pathogenic and saprophytic strains of leptospires. In particular, a major protein doublet of $33-34 \mathrm{kDa}$ has been shown to be conserved among the different genera of the family Leptospiraceae (Kelson et al., 1988).

The genes encoding the flagellar proteins from another member of the order Spirochaetales, Treponema pallidum, have been cloned and sequenced (Pallesen \& Hindersson, 1989; Isaacs et al., 1989; Champion et al., 1990). Three of these proteins, a 31 and $31.3 \mathrm{kDa}$ doublet and a $34.5 \mathrm{kDa}$ species, have been identified as endoflagellar subunit proteins (Pallesen \& Hindersson, 1989; Champion et al., 1990) designated FlaB1 to FlaB3 respectively. An additional $37 \mathrm{kDa}$ protein has been identified as the endoflagellar sheath protein, FlaA (Isaacs et al., 1989). In this paper we report the cloning, expression and sequencing of a gene encoding a $32 \mathrm{kDa}$ endoflagellar subunit gene from $L$. borgpetersenii (formerly L. interrogans) serovar hardjo (Yasuda et al., 1987).

The sequence data reported in this paper will appear in the GenBank Nucleotide Sequence Database under the accession number M61910.

\section{Methods}

Bacterial strains and plasmids. L. borgpetersenii serovar hardjo strain L171 (Farrelly et al., 1987) was cultured in Tween 80-bovine albumin (EMJH) medium with added pyruvate (Johnson et al., 1973). All Escherichia coli recombinants were derivatives of strain DH5a (Bethesda Research Laboratories) and were cultured in $2 \times$ YT medium (Vieira \& Messing, 1982), supplemented with ampicillin $\left(100 \mu \mathrm{g} \mathrm{ml}^{-1}\right)$ as required. All recombinant plasmids were derivatives of the cloning vector pUC18 (Yanisch-Perron et al., 1985).

Preparation and analysis of DNA. Whole-cell leptospiral DNA was prepared from serovar hardjo strain L171 as described previously (Marshall et al., 1984; Doherty et al., 1989). E. coli plasmid DNA was isolated by the alkaline lysis method (Birnboim \& Doly, 1979). Ligation, transformation and agarose gel electrophoresis methods were as described by Maniatis et al. (1982). Restriction endonucleases, T4 ligase and calf intestinal alkaline phosphatase (molecular biology grade) were from either Promega or Boehringer-Mannheim.

Preparation of L. borgpetersenii gene bank. L. borgpetersenii DNA $(20 \mu \mathrm{g})$ was partially digested with $\operatorname{Sau} 3 \mathrm{~A}$, excised from a $1 \%$ lowmelting-point agarose gel and ligated overnight at $15^{\circ} \mathrm{C}$, within the gel matrix, with $1 \mu \mathrm{g}$ of BamHI-digested, dephosphorylated pUC18 (Yanisch-Perron et al., 1985). The ligation mixture was used to transform competent $E$. coli $\mathrm{DH} 5 \alpha$ cells to ampicillin resistance. Transformants were selected on $2 \times \mathrm{YT}$-ampicillin $\left(100 \mu \mathrm{g} \mathrm{ml}^{-1}\right)$ plates containing X-Gal (5-bromo-4-chloro-3-indolyl $\beta$-D-galactopyranoside). Colourless recombinant clones were screened by colony immunoassay as described previously (Doherty et al., 1989).

Antiserum production. All antisera were produced in New Zealand White rabbits. Antiserum used in the colony immunoassay, SB288, was kindly provided by S. Ballard (Department of Microbiology, Monash University) and contained antibodies against a large range of leptospiral serovar hardjo proteins as assessed by Western blotting against leptospiral whole-cell lysate. It was absorbed with lysed $E$. coli DH $5 \alpha$ cells prior to use. The R390 antiserum used to detect the flagellar subunits in Western blotting was prepared against isolated, SDSPAGE-denatured flagellum proteins consisting primarily of the genus 
cross-reactive 33-34 kDa doublet (Kelson et al., 1988), from L. interrogans serovar pomona (Boulard \& Lecroisey, 1982).

Protein electrophoresis and immunoblotting. Leptospiral and E. coli components were separated by electrophoresis on discontinuous 10-15\% (w/v) SDS-polyacrylamide gels (Laemmli, 1970). Leptospiral sonicates were prepared as described previously (Adler et al., 1980). $E$. coli preparations were prepared in sample buffer containing SDS $(1.3 \%, \mathrm{w} / \mathrm{v})$, bromophenol blue $(0.002 \%, \mathrm{w} / \mathrm{v})$ and glycerol $(4 \%, \mathrm{v} / \mathrm{v})$ immersed in boiling water for $10 \mathrm{~min}$ and then centrifuged at $11600 \mathrm{~g}$ for $5 \mathrm{~min}$ prior to loading. Flagellar protein was prepared by boiling in sample buffer for $5 \mathrm{~min}$. Electrophoresis conditions, Western blotting and immunostaining procedures have been described previously (Chapman et al., 1987), as has the method for eluting antibodies from nitrocellulose (Beall \& Mitchell, 1986).

Isolation of fagella. Flagella isolated from approximately $5 \times 10^{11}$ cells of strain L171 were prepared as described by Chang \& Faine (1970) and were further purified by caesium chloride density-gradient centrifugation (Kelson et al., 1988).

DNA hybridization. Southern blots were performed as described by Southern (1975). Randomly primed DNA was labelled with [ ${ }^{32}$ P]dATP (Amersham) using an oligolabelling kit (Bresatec) following the supplied protocol. Prehybridization and hybridization solutions contained $50 \%(\mathrm{v} / \mathrm{v})$ formamide, $1 \%(\mathrm{w} / \mathrm{v})$ SDS, $0.5 \%(\mathrm{w} / \mathrm{v})$ skim milk powder, $4 \mathrm{~mm}$-EDTA, $32 \mathrm{~mm}-\mathrm{NaOH}, 40 \mathrm{~mm}-\mathrm{NaH}_{2} \mathrm{PO}_{4}, 0.72 \mathrm{M}-\mathrm{NaCl}$ and $0.3 \mathrm{mg}$ salmon sperm DNA $\mathrm{ml}^{-1}$. Following hybridization overnight, blots were washed under high-stringency conditions prior to autoradiography at $-70^{\circ} \mathrm{C}$ using intensifying screens.

DNA sequencing and computer analysis. DNA sequencing was performed using $\left[\alpha^{-35}\right.$ S]dATP (Amersham) and a T7 sequencing kit (Pharmacia) by following the manufacturer's protocol for doublestranded sequencing. DNA to be sequenced was purified on a caesium chloride gradient or by using Geneclean (Bio 101). Unequivocal sequence was obtained on both DNA strands. Nucleotide and amino acid sequence data were analysed using MELBDBSYS, a suite of programs developed by the Walter and Eliza Hall Institute, the Ludwig Institute for Cancer Research and the Howard Florey Institute, Melbourne, Australia. The Treealign program, which performs phylogenetic alignment of homologous sequences (Hein, 1989a, b), was used to compare the FlaB amino acid sequence with other flagellin proteins.

\section{Results}

\section{Cloning and definition of the fla $B$ coding region}

Recombinant clones containing chromosomal DNA isolated from serovar hardjo strain L171 were initially screened by colony immunoassay using SB288 antihardjo antiserum. Positive clones were further analysed by Western blotting. One clone, carrying the recombinant plasmid pLBA21, reacted weakly in colony immunoassays and two weak bands, 32 and $28 \mathrm{kDa}$ in size were detected by Western blotting. To determine whether the cloned products were flagellar antigens they were further analysed by Western blotting using R390 antiserum raised against denatured flagellar components. The antiserum reacted strongly with the 32 and $28 \mathrm{kDa}$ bands (Fig. 1a). Antiserum raised against undenatured whole flagella did not react with the cloned products by Western blotting (data not shown).

The plasmid pLBA21 (Fig. 2) contained a $3.9 \mathrm{~kb}$ Sau3A leptospiral DNA fragment inserted into the BamHI site of pUC18. By subcloning and subsequent testing for antigen expression using Western blotting with R390 antiserum, the gene encoding the $32 \mathrm{kDa}$ protein was localized to a central $1.2 \mathrm{~kb} \mathrm{NruI}$ fragment (Fig. 2), which also contained an internal $N r u$ I site. In accordance with the terminology used for the cloned $T$. pallidum genes (Pallesen \& Hindersson, 1989; Champion et al., 1990), the gene encoding the $32 \mathrm{kDa}$ protein was designated $f a B$. There was no expression of the 32 or $28 \mathrm{kDa}$ proteins when the entire $3.9 \mathrm{~kb}$ region encoded by pLBA 21 , or the $1.2 \mathrm{~kb} \mathrm{NruI}$ fragment from pLBA38, was inserted in the opposite orientation relative to the lac Z promoter (Fig. 2). Expression of the cloned products encoded by pLBA21 therefore appeared to be under the control of the $l a c Z$ promoter in pUC18, indicating a direction of transcription from left to right in Fig. 2. Interestingly, the strain harbouring the Pst I subclone pLBA31 produced an $18 \mathrm{kDa}$ protein identified by $\mathrm{R} 390$ antiserum. To confirm the origin of the insert, chromosomal DNA isolated from strain L171 was digested with EcoRV and ClaI and probed by Southern blotting using the $1.2 \mathrm{~kb} \mathrm{NruI}$ fragment from pLBA38. The probe hybridized to a single $3.4 \mathrm{~kb}$ chromosomal band which was of identical size to the fragment obtained after EcoRV/ClaI digestion of pLBA21 (data not shown). To determine whether any other regions of pLBA21 had flaB-related sequences, a $0.5 \mathrm{~kb} P$ Pst $\mathrm{I} / \mathrm{Sal} \mathrm{I}$ fragment contained wholly within the $f a B$ gene was used to probe pLBA21 digested with $N r u I$. The probe hybridized to three bands, of $1.2,0.7$ and $0.5 \mathrm{~kb}$, which corresponded to the partial $N r u$ I digestion of the central $1.2 \mathrm{~kb} \mathrm{NruI}$ region encoded by pLBA38 (Fig. 2).

\section{Serological relatedness of the cloned antigens}

A cell lysate of E. coli containing pLBA21 was separated by SDS-PAGE, and following Western transfer and overnight incubation with anti-flagellar serum (R390), antibodies were eluted from the 32 and $28 \mathrm{kDa}$ protein bands. These antibodies were reacted by Western blotting with serovar hardjo L171 sonicate, isolated flagella and a cell preparation of the FlaB clone, harbouring pLBA21 (Fig. $1 b, c$ ). Antibodies eluted from the $32 \mathrm{kDa}$ band reacted with the $28 \mathrm{kDa}$ band and also with the $33 \mathrm{kDa}$ band present in both the leptospiral sonicate and the purified flagella preparation and corresponding to the lower doublet band described by Kelson et al. (1988). Antibodies eluted from the $28 \mathrm{kDa}$ band showed a similar reactivity pattern, and reacted with the $32 \mathrm{kDa}$ band. 


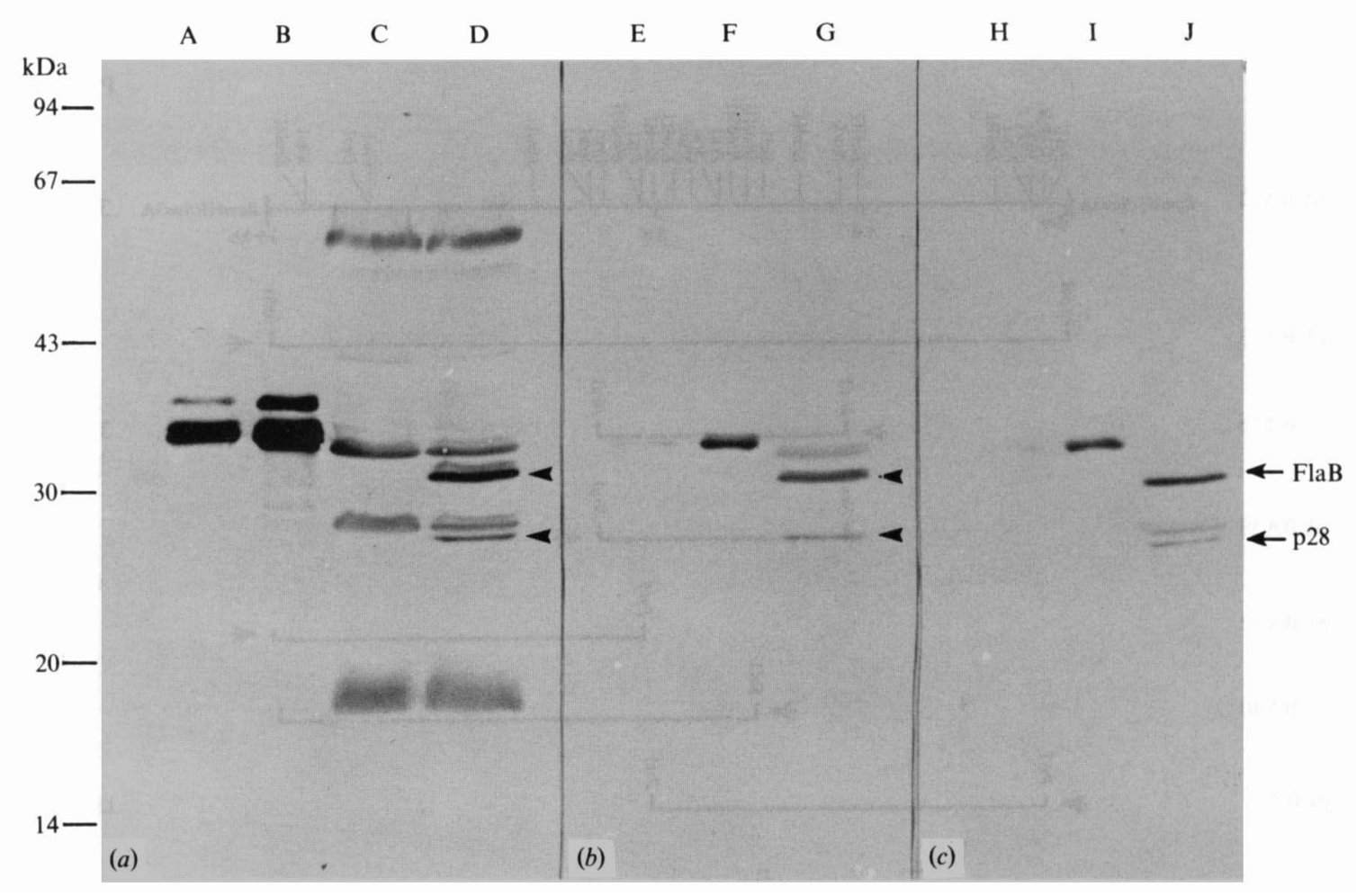

Fig. 1. Western blot analysis of the cloned flagellin proteins immunostained with anti-flagellar serum R390 (a), antibodies eluted from the $32 \mathrm{kDa}$ FlaB band $(b)$, or antibodies eluted from the $28 \mathrm{kDa}$ band $(c)$. Lanes: A, E and H, L171 whole-cell sonicate; B, F and I, purified L171 flagella; D, G and J, cell extracts prepared from $E$. coli DH5 $\alpha$ cells containing pLBA21; C, control strain of $E$. coli DH5 $\alpha$ containing pUC18. The $32 \mathrm{kDa}$ FlaB protein and the $28 \mathrm{kDa}$ protein (p28) are indicated by arrows on the right. Minor bands in lanes $\mathrm{G}$ and $\mathrm{J}$ are due to co-eluted $E$. coli antibodies and are also seen in the $E$. coli control (lane $\mathrm{C}$ ). The numbers on the left indicate the positions of the standard molecular mass markers.

\section{Nucleotide sequence of the cloned flaB gene and the deduced amino acid sequence}

DNA sequence analysis of a series of overlapping subclones was used to obtain the unequivocal nucleotide sequence of the $1.2 \mathrm{~kb} N r u$ I fragment from pLBA21, on both DNA strands (Fig. 3). An open reading frame of 849 nucleotides, corresponding to 283 amino acids, was identified. The calculated molecular mass of the encoded protein was $31.3 \mathrm{kDa}$. A consensus E. coli ShineDalgarno sequence was present 7 base pairs upstream from the initiation codon. An inverted repeat sequence $\left[\Delta G=-22.8 \mathrm{kcal} \mathrm{mol}^{-1}\left(-95.4 \mathrm{~kJ} \mathrm{~mol}^{-1}\right)\right]$ which may function as a rho-independent transcriptional terminator was located 37 bases downstream of the stop codon (Tinoco et al., 1973). There were no identifiable promoters upstream of $f a B$ within the sequenced region. The $\mathrm{G}+\mathrm{C}$ content of $f a B$ was $54.7 \mathrm{~mol} \%$, in contrast to the reported $39 \mathrm{~mol} \% \mathrm{G}+\mathrm{C}$ content of serovar hardjo genomic DNA (LeFebvre et al., 1987). The encoded protein contained $31(10.9 \%)$ acidic and $33(11.7 \%)$ basic amino acids. Eighty-nine $(31 \%)$ of the amino acids were hydrophobic, but there were no significant hydrophobic domains within the protein. There was a greater similarity of codon usage between the $f a B$ gene and $E$. coli genes (Ikemura \& Ozeki, 1982) than with codon usage observed with the sphingomyelinase $\mathrm{C}$ gene from serovar hardjo (Segers et al., 1990), in particular for the amino acids Gln, His, Phe, Tyr and Val. Interestingly, CCG was the only codon used for the amino acid Pro.

Comparative amino acid sequence analysis of the flagellin proteins

The predicted amino acid sequence of the serovar hardjo L171 FlaB protein had significant sequence similarity with flagellar proteins from other bacteria (Fig. 4). The aligned sequences do not include Salmonella typhimurium, Campylobacter coli, Rhizobium meliloti, Serratia marcescens or E. coli flagellins due to the greater length of these amino acid sequences. However, these proteins are included in a dendrogram derived from an alignment of the amino acid sequences (Fig. 5). The alignment data revealed a close relationship between the 


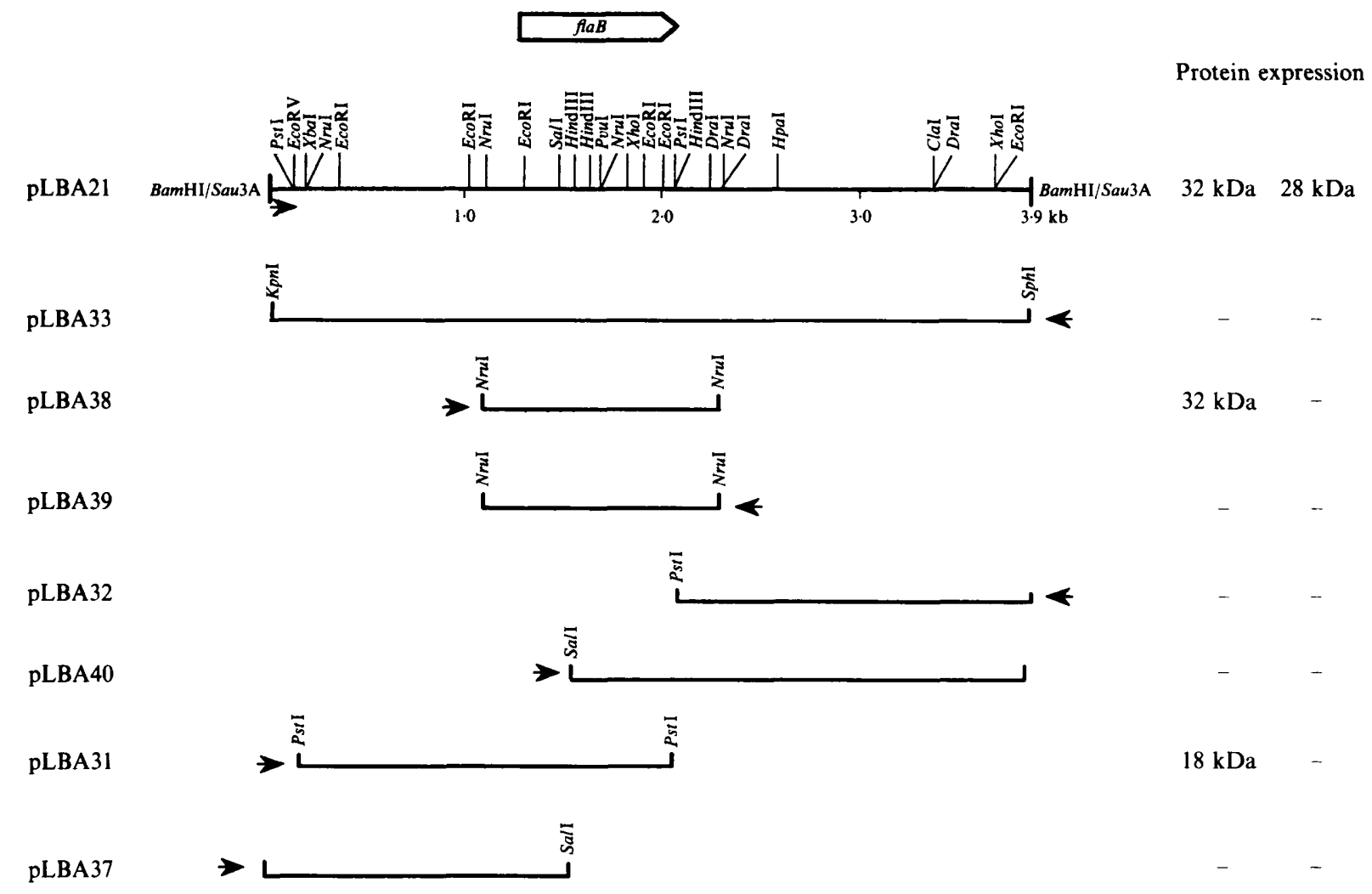

Fig. 2. Restriction maps of pLBA21 and derived subclones. The location of the flaB gene is shown. Arrows for each plasmid indicate the direction of transcription from the lac promoter. Proteins were detected with anti-flagellar serum R390 by Western blotting analysis of the recombinant strains harbouring the plasmids. A dash indicates that no proteins were detected.

T. pallidum FlaB1, B2 and B3 proteins and L. borgpetersenii FlaB, with homologies of $56-59 \%$. The relationship was more evident if conserved amino acid changes were considered, resulting in similarities of $88-89 \%$. Flagellins from Roseburia cecicola, Borrelia burgdorferi and Bacillus subtilis were less similar to L. borgpetersenii, having $38 \%, 40 \%$ and $41 \%$ homology, respectively. Caulobacter crescentus flagellin was the least related of those studied, having only $18 \%$ homology with FlaB. The dendrogram (Fig. 5) indicates that $L$. borgpetersenii is phylogenetically more distant from Borrelia burgdorferi than Bacillus subtilis. The close phylogenetic relatedness of the FlaB proteins from $L$. borgpetersenii and $T$. pallidum is apparent.

\section{Discussion}

The flagellin proteins from a diverse range of bacteria have previously been cloned, including those from $B$. burgdorferi and $T$. pallidum which, like leptospires, are members of the order Spirochaetales. Leptospiral flagellar components have been identified in SDS-
PAGE gels as four major protein bands of $31 \mathrm{kDa}$, $37 \mathrm{kDa}$ and a 33-34 kDa doublet (Kelson et al., 1988). The doublet observed in profiles of isolated leptospiral flagella has previously been shown to be conserved among the different genera of the family Leptospiraceae (Kelson et al., 1988). A similar flagellar doublet profile was observed in flagella isolated from $T$. pallidum and shown to consist of two subunit proteins, FlaBl and FlaB2. Here we report the cloning and expression in E. coli of a flagellin gene from L. borgpetersenii. The recombinant clone carrying pLBA21 produced two proteins, both of which were expressed under the control of the lac $Z$ promoter. These consisted of the $31 \mathrm{kDa}$ FlaB protein and a $28 \mathrm{kDa}$ protein designated $\mathrm{p} 28$. Antisera raised against denatured flagellar proteins from an SDSPAGE gel reacted with the cloned proteins. However, antisera raised against non-denatured leptospiral flagella did not react with the FlaB or p28 proteins, suggesting that the epitopes recognized by these antibodies were only exposed by the denaturation of flagellin. The gene encoding FlaB was localized to a central $\mathrm{NruI}$ region of pLBA21. A PstI site was present six nucleotides upstream of the $f a B$ stop codon and yet the Pst I subclone pLBA31 produced an $18 \mathrm{kDa}$ protein that was much 
GATTGATAATTCATTGTTACTCCGTGATAGGAGGACGCCTGGTCTGTCAGGTGGTCTGAATATTGTCCAT $\begin{array}{lllllll}10 & 20 & 30 & 40 & 50 & 60 & 70\end{array}$ $\begin{array}{cccccc}\text { CCCGGAGCACCGGACAGACCATGTCCGGCGGCAGATAGGGAGATTTGCCGTTCATCTCTACAAAGGAG } & 100 & 120 & 130\end{array}$ $\begin{array}{lllllllllllllllllllll}M & I & I & N & H & N & L & S & A & V & N & S & H & R & S & L & K & F & N & E & L\end{array}$ TGTAGAATGATTATCAATCACAACCTGAGCGCGTGAATTCTCACCGTTCTCTAAAGTTCAACGAGCTTG $\begin{array}{llllllllllllllllllllllll}A & V & D & K & T & M & K & A & I & S & S & G & M & R & I & N & S & A & A & D & D & A & S & G\end{array}$ CTGTGGACAAGACGATGAAGGCTTTGTCTTCCGGTATGCGGATCAATTCCGCGGCGGACGACGCTTCCGG $\begin{array}{lllllll}220 & 230 & 240 & 250 & 260 & 270 & 280\end{array}$

$\begin{array}{llllllllllllllllllllllll}I & A & V & S & E & K & L & R & T & Q & I & N & G & I & R & Q & A & E & R & N & T & E & D\end{array}$ ACTCGCGGTTTCTGAAAAGCTAAGAACGCAGATCAACGGTCTGCGTCAGGCCGAAAGAAACACCGAAGAC

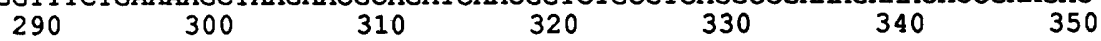

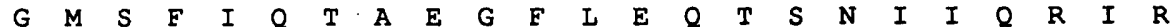
GGGATGAGCTTCATTCAAACTGCCGAGGGTTTCCTCGAACAGACGTCGAACATCATTCAGAGAATCCGGG $\begin{array}{llllll}360 & 370 & 380 & 390 & 400 & 410\end{array}$

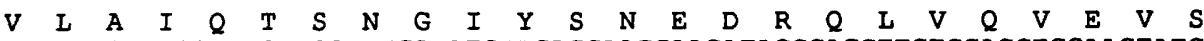
TGCTTGCCATCCAGACCTCGAATGGTATCTACAGCAACGAAGATAGGCAGCTTGTGCAGGTGGAAGTATC $\begin{array}{lllllll}430 & 440 & 450 & 460 & 470 & 480 & 490\end{array}$

$\begin{array}{lllllllllllllllllllllll}A & L & V & D & E & V & D & R & I & A & S & Q & A & E & F & N & K & F & K & L & F & E & G\end{array}$ TGCGCTGGTGGACGAAGTCGACCGAATCGCTTCTCAGGCTGAATTTAATAAGTTCAAGCTTTTCGAGGGG

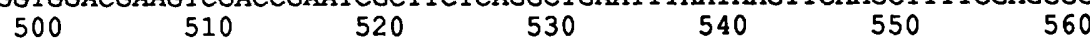

$\begin{array}{llllllllllllllllllllllll}Q & F & A & R & G & S & R & V & A & S & M & W & F & H & M & G & P & N & Q & N & Q & R & E\end{array}$ CAATTCGCAAGAGGTTCACGGGTCGCGTCCATGTGGTTTCATATGGGACCGAACCAAAATCAGCGAGAGA

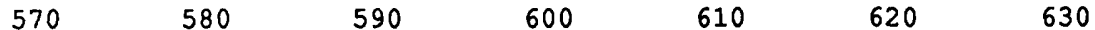

$\begin{array}{llllllllllllllllllllllll}R & F & Y & I & G & T & M & T & S & K & A & L & K & L & V & K & A & D & G & R & P & I & A & I\end{array}$ GATTTTACATCGGCACGATGACTTCGAAAGCCCTGAAGCTTGTAAAGGCGGACGGGAGACCGATCGCGAT $\begin{array}{lllllll}640 & 650 & 660 & 670 & 680 & 690 & 700\end{array}$

$\begin{array}{lllllllllllllllllllllll}S & S & P & G & E & A & N & D & V & I & G & I & A & D & A & A & L & T & R & -I & M & K & 0\end{array}$ $\begin{array}{cccccc}\text { TTCTTCTCCGGGAGAAGCCAACGATGTTATCGGTTTAGCGGATGCGCTCTTACGAGGATCATGAAGCAG } \\ 710 & 720 & 730 & 740 & 750 & 760\end{array}$

$\begin{array}{lllllllllllllllllllllll}R & A & D & M & G & A & \mathbf{Y} & \mathbf{Y} & \mathbf{N} & \mathbf{R} & \mathrm{L} & \mathbf{E} & \mathbf{Y} & \mathbf{T} & \mathbf{A} & \mathbf{K} & \mathbf{G} & \mathbf{L} & \mathbf{M} & \mathbf{G} & \mathbf{A} & \mathbf{Y} & \mathbf{E}\end{array}$ AGAGCGGATATGGGGGCTTATTACAATAGGCTCGAGTATACCGCAAAAGGGCTGATGGGTGCATATGAAA $\begin{array}{lllllll}780 & 790 & 800 & 810 & 820 & 830 & 840\end{array}$

$\begin{array}{llllllllllllllllllllllll}N & M & Q & A & S & E & S & R & I & R & D & A & D & M & A & E & E & V & V & S & L & T & T & K\end{array}$ ATATGCAAGCATCGGAATCCAGAATTCGGGACGCCGATATGGCGGAGGAAGTTGTCTCGCTGACCACAAA

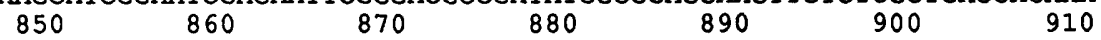

\begin{tabular}{lllllllllllllllllllllll}
\hline & $I$ & $L$ & $V$ & $Q$ & $S$ & $G$ & $T$ & $A$ & $M$ & L & $A$ & $Q$ & $A$ & $N$ & $M$ & $K$ & $P$ & $N$ & $S$ & $V$ & $L$ & $K$
\end{tabular} ACAAATACTCGTTCAGAGTGGTACGGCAATGTTAGCGCAGGCAAATATGAAACCGAATTCGGTTCTCAAG

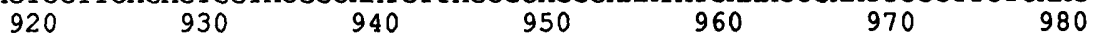

I I $Q$ H $I$ *

CTTCTGCAGCATATCTAAAGGAAGCCTTCCAGGAGGGAAGGTAGACAAAAAGGTTCCACCGGGAGGCATC $\begin{array}{lllllll}990 & 1000 & 1010 & 1020 & 1030 & 1040 & 1050\end{array}$

TCTTCCGGTGGATTTTTTATAAGAATTTCGAATTATAAAGTTTTAGAAAAACCTCCGTAGATAGTTCATA

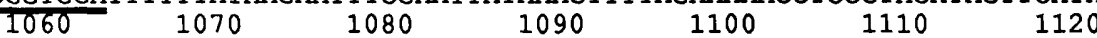

ATCATTTTTAAGAATATTCTAATTTTTGAATTTAAAAGATTAAGGCCGGTTCCGGAATCGTCCAATGCCG

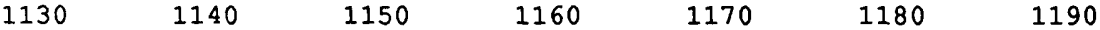

TATCTTACGGAGATTTT

1200

Fig. 3. Nucleotide sequence of the 1207 bp NruI fragment of pLBA38 and deduced amino acid sequence. An $E$. coli consensus ShineDalgarno sequence is underlined at position 136. A second potential ribosome-binding sequence is also underlined at position 213 followed by a putative internal initiation codon at position 225 . The translation stop codon is indicated by the asterisk. A potential transcription termination signal sequence downstream of $f a B$ is double underlined. 

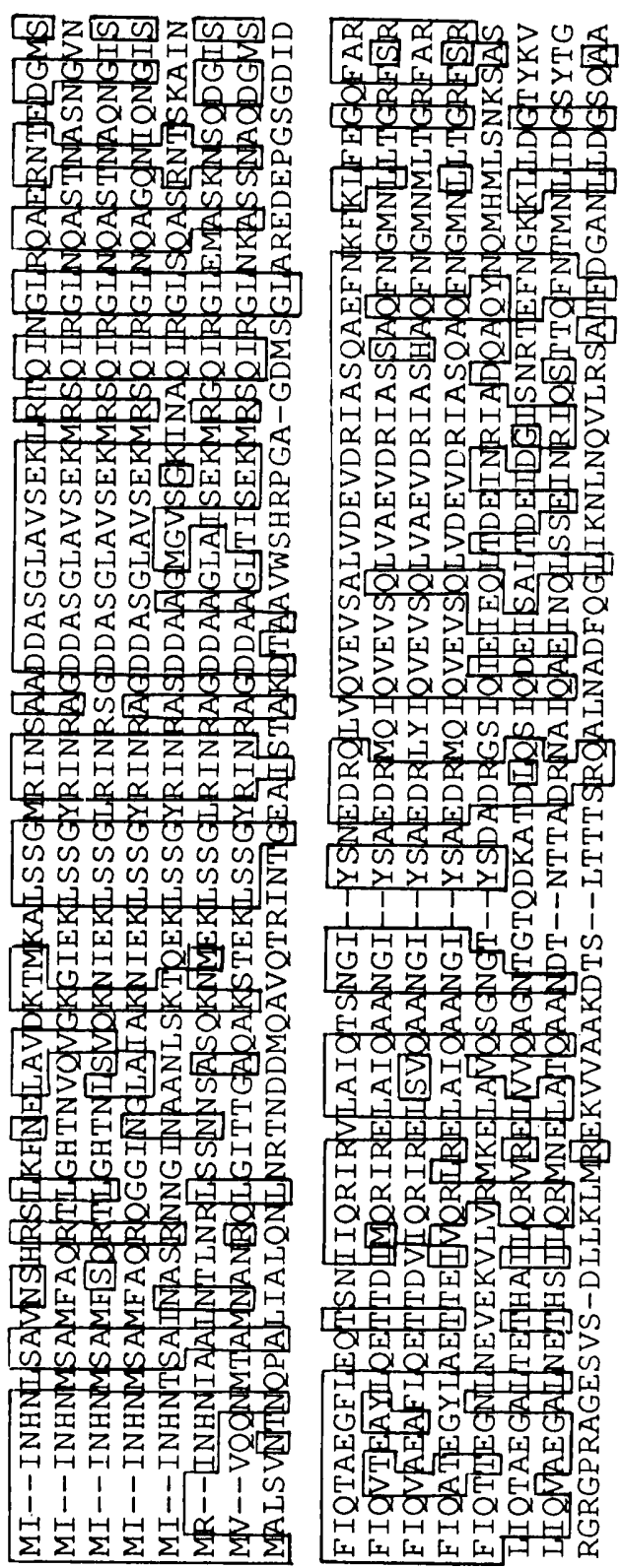

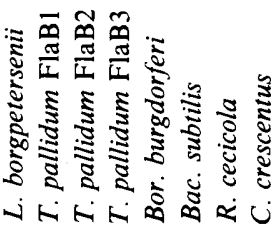

$: \approx \widetilde{\infty} \approx 0$

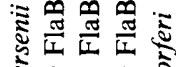

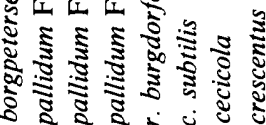

ن

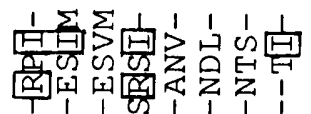

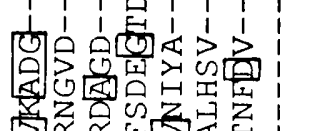

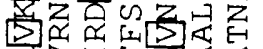

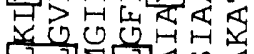

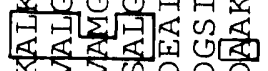

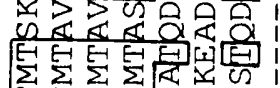

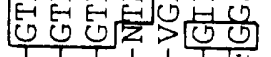

समम1

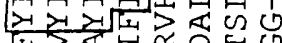

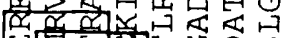

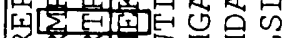

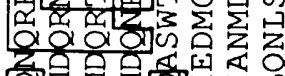

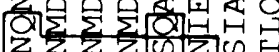

Kर

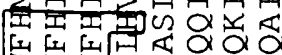

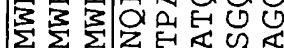

w w w क क

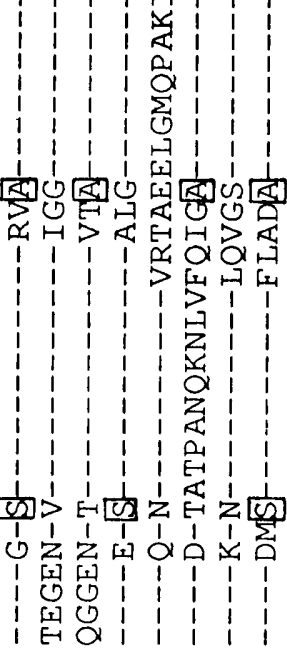

Lar

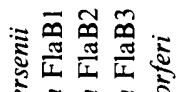

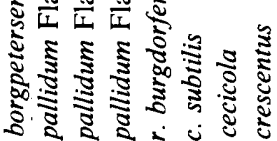

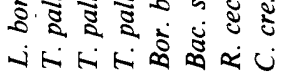

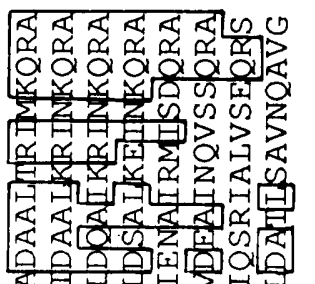

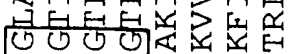

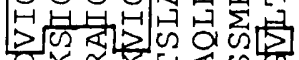

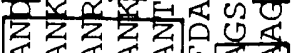

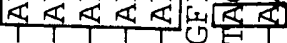

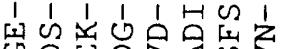

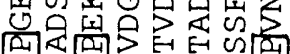

包比

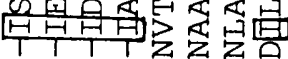

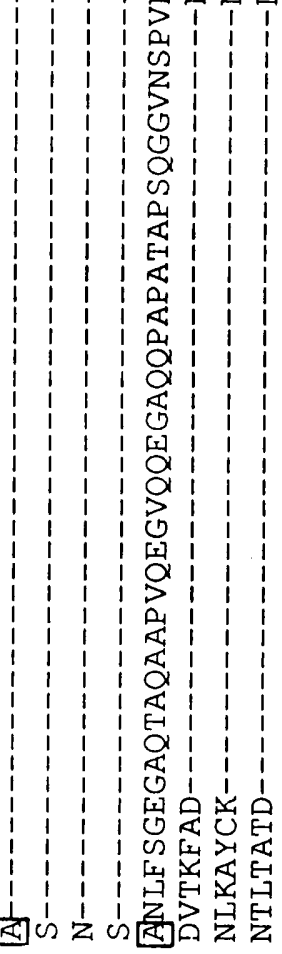

$\bar{x} \tilde{\oplus}$

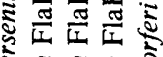

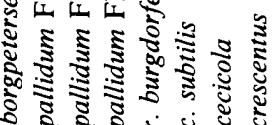

ititio
$1 \quad 111110$

$1100 \%$

นี

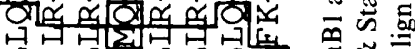

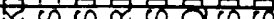

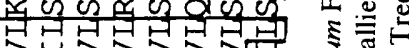

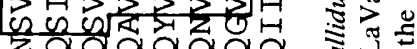

保

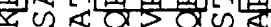

¿ 0 o o व o

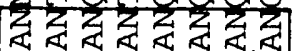

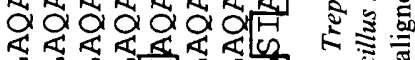

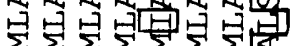

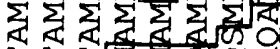

动

un wकरत

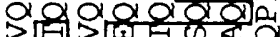

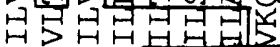

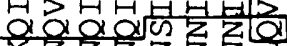

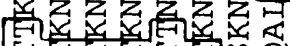

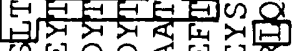

की

5 होडाइए

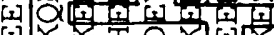

दो

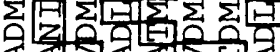

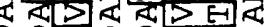

१िवे विकि

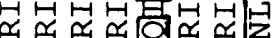

心的的的0

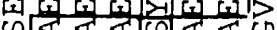

दि

वर्व सिख्या

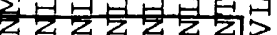

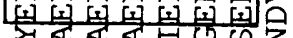

र

म

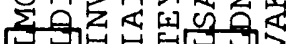

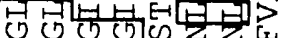

दरवz在

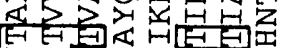

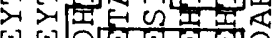

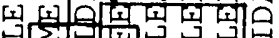

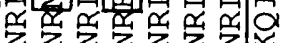

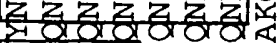

作

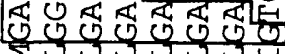

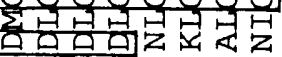

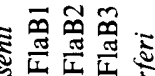

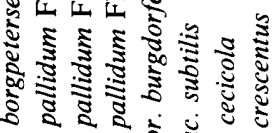

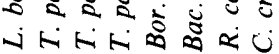

范

월

ส

๘

号

83

$\therefore \dot{2}$

ริ용

ริ

造范

击

옹

크

品

要密

密

옳

む ఖ

ฮ્ छ

这

눙

空文

ह

可

䓀

范

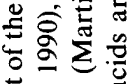

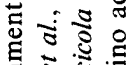

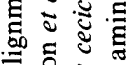

文产

จ हี

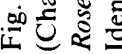




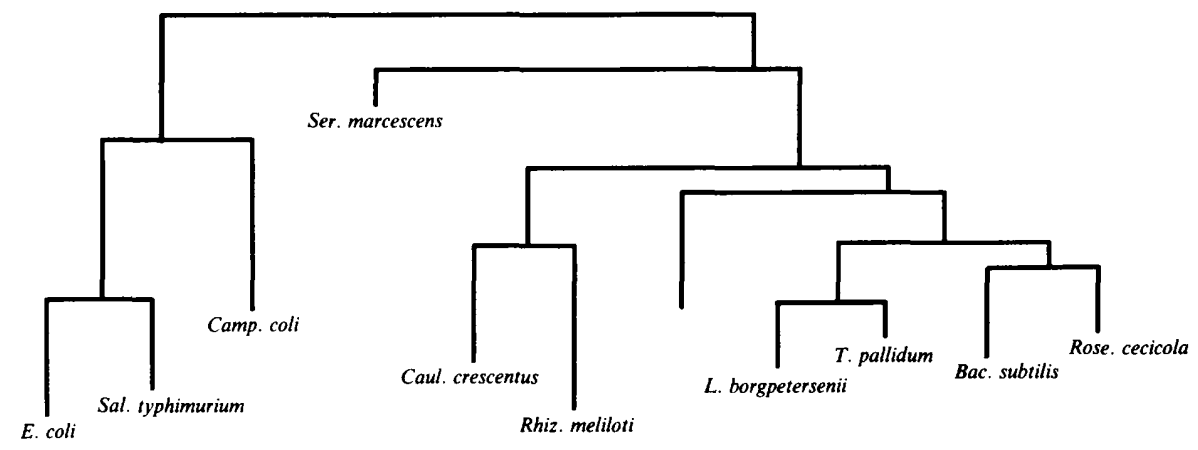

Fig. 5. Dendrogram showing relatedness of the flagellins from the following organisms: Escherichia coli (Kuwajima et al., 1986), Salmonella typhimurium (Joys, 1985), Campylobacter coli (FlaB) (Guerry et al., 1990), Serratia marcescens (Harshey et al., 1989), Caulobacter crescentus (Gill \& Agabian, 1983), Rhizobium meliloti (FlaA) (Pleier \& Schmitt, 1989), Borrelia burgdorferi (Wallich et al., 1990), Leptospira borgpetersenii (this work), Treponema pallidum (FlaB1) (Champion et al., 1990), Bacillus subtilis (LaVallie \& Stahl, 1989) and Roseburia cecicola (Martin \& Savage, 1988).

smaller than the predicted size of the truncated product $(31 \mathrm{kDa})$. It is possible that the truncated product is less stable than the complete protein and is degraded to produce the $18 \mathrm{kDa}$ protein seen in Western blots.

The FlaB protein and the p28 protein were antigenically related, as shown from the results of experiments in which specific antibodies eluted from each of the cloned proteins reacted with each other and with only the $33 \mathrm{kDa}$ flagellar protein in leptospires. Interestingly, antibodies eluted from either FlaB or p28 did not react with the larger of the two leptospiral flagellar doublet proteins, indicating that these proteins were antigenically unrelated. This was in contrast to the findings in $T$. pallidum, where the two components of the doublet were both flagellin subunit proteins (FlaB1 and FlaB2) and were antigenically related. Further studies are required to determine whether the larger leptospiral protein constitutes a second flagellin subunit, which is antigenically distinct from FlaB.

The location of the gene encoding p28 is uncertain. Within the $f a B$ gene coding region there is a potential in-frame internal initiation (nucleotide 225) codon preceded by a weak ribosome-binding site (Fig. 3). The calculated molecular mass of a protein initiating at this site is $28.3 \mathrm{kDa}$. The existence of a second gene encoding p28 is unlikely as none of the subclones expressed p28 (Fig. 2). Moreover, in Southern blots only the NruI fragments encoded by pLBA 38 hybridized with the $f a B$ gene. An alternative explanation for our data is that $\mathrm{p} 28$ is a breakdown product of $\mathrm{FlaB}$, especially since additional bands of lower molecular mass were occasionally observed in profiles of strains carrying pLBA21.

The apparent molecular mass of the cloned FlaB protein in SDS-PAGE gels was approximately $32 \mathrm{kDa}$, close to that calculated from the deduced amino acid sequence $(31.3 \mathrm{kDa})$. The size of the cloned polypeptide was smaller than the $33 \mathrm{kDa}$ flagellar protein in leptospires. The precise reason for this difference is unclear. One possibility may be post-translational modification of the protein in leptospires, such as the addition of a lipid moiety. However, the protein contains neither cysteine residues nor any identifiable putative signal pepide sequences which are necessary for the addition of lipids (Yamaguchi et al., 1988). Although rarely reported in bacteria, the possibility nevertheless exists of the addition of sugar residues to the protein (Lechner, 1989). Indeed the flagellins of Halobacterium halobium are glycosylated and the amino acid sequence which surrounds $N$-glycosidic linkages is commonly of the formula Asn-X-Thr(Ser) (Wieland et al., 1985). This sequence is present in the leptospiral FlaB protein six amino acids from the $\mathrm{N}$-terminus. Previous comparisons of flagellins from different genera of bacteria have revealed extensive homology in the $\mathrm{N}$-terminal and $\mathrm{C}$-terminal regions and these regions in leptospiral flagellin are also highly conserved (Fig. 4). The amino acid sequence alignment also showed a high degree of homology between FlaB proteins from $L$. borgpetersenii strain $\mathrm{L} 171$ and $T$. pallidum. The $\mathrm{G}+\mathrm{C}$ content of the leptospiral $f a B$ gene is significantly higher than the reported $39 \mathrm{~mol} \% \mathrm{G}+\mathrm{C}$ content of the leptospiral genome (LeFebvre et al., 1987), but remarkably similar to the $\mathrm{G}+\mathrm{C}$ content of the $T$. pallidum genome (Miao \& Fieldsteel, 1978) and the T. pallidum flaB genes (Pallesen \& Hindersson, 1989; Champion et al., 1990). Based on these results, we suggest that the FlaB protein from $L$. borgpetersenii and the FlaB proteins of $T$. pallidum may have a common ancestral gene. This hypothesis is consistent with the close phylogenetic relationship between the FlaB proteins from the two species (Fig. 5). The mechanism by which the gene may have been introduced into $L$. borgpetersenii is not known since genetic exchange has not been demonstrated with these organisms. 
This work was supported by a project grant from the National Health and Medical Research Council, Canberra, Australia. The authors wish to thank Trudi Bannam, Susan Ballard, Margaret Katz and Pauline Howarth for their advice and technical assistance.

\section{References}

Adler, B., Murphy, A. M., Locarnini, S. A. \& Faine, S. (1980). Detection of specific anti-leptospiral immunoglobulins $M$ and $G$ in human serum by solid-phase enzyme-linked immunosorbent assay. Journal of Clinical Microbiology 11, 452-457.

BeALl, J. A. \& Mitchell, G. F. (1986). Identification of a particular antigen from a parasitic cDNA library using antibodies affinity purified from selected portions of Western blots. Journal of Immunological Methods 86, 217-223.

BIRNBOIM, H. C. \& DOLY, J. (1979). A rapid alkaline extraction procedure for screening recombinant plasmid DNA. Nucleic Acids Research 7, 1513-1523.

Boulard, C. \& Lecroisey, A. (1982). Specific antisera produced by direct immunization with slices of polyacrylamide gel containing small amounts of protein. Journal of Immunological Methods 50, 221-226.

Champion, C. I., Miller, J. N., Lovett, M. A. \& Blanco, D. R. (1990). Cloning, sequencing and expression of two class B endoflagellar genes of Treponema pallidum subsp. pallidum encoding the 34.5 and $31 \cdot 0$-kilodalton proteins. Infection and Immunity 58, $1697-1704$.

Chang, A. \& FaINe, S. (1970). Electron-microscopic evidence for reactions of axial filaments of Leptospira with $\operatorname{IgM}$ and $\operatorname{IgG}$ antibodies. Bulletin of the World Health Organization 43, 571-577.

Chapman, A. J., AdLeR, B. \& FaINe, S. (1987). Genus-specific antigens in Leptospira revealed by immunoblotting. Zentralblatt für Bakteriologie, Mikrobiologie und Hygiene, A 264, 279-293.

Doherty, J. P., Adler, B., ROOD, J. I., Billington, S. J. \& Faine, S. (1989). Expression of two conserved leptospiral antigens in Escherichia coli. Journal of Medical Microbiology 28, 143-149.

FARrelly, H. E., AdLeR, B. \& Faine, S. (1987). Opsonic monoclonal antibodies against lipopolysaccharide antigens of Leptospira interrogans serovar hardjo. Journal of Medical Microbiology 23, 1-7.

Gill, P. R. \& Agabian, N. (1983). The nucleotide sequence of the $M_{\mathrm{r}}=28500$ flagellin gene of Caulobacter crescentus. Journal of Biological Chemistry 258, 7395-7401.

Guerry, P., Logan, S. M., Thornton, S. \& Trust, T. J. (1990). Genomic organization and expression of Campylobacter flagellin genes. Journal of Bacteriology 172, 1853-1860.

HaRshey, R. M., Estepa, G. \& Yanagi, H. (1989). Cloning and nucleotide sequence of a flagellin-coding gene (hag) from Serratia marcescens 274 . Gene 79, 1-8.

Hein, J. (1989a). A new method that simultaneously aligns and reconstructs ancestral sequences for any number of homologous sequences, when the phylogeny is given. Molecular Biology and Evolution 6, 649-668.

HeIN, J. $(1989 b)$. A tree reconstruction method that is economical in the number of pairwise comparisons used. Molecular Biology and Evolution 6, 669-684.

IKemura, T. \& Ozexi, H. (1982). Codon usage and transfer RNA contents: organism-specific codon-choice patterns in reference to the isoacceptor contents. Cold Spring Harbor Symposia on Quantitative Biology 47, 1087-1097.

IsaAcs, R. D., Hanke, J. H., Guzman-Verduzco, L., Newport, G., agabian, N., Norgard, M. V., Lukehart, S. A. \& Radolf, J. D. (1989). Molecular cloning and DNA sequence analysis of the 37kilodalton endoflagellar sheath protein gene of Treponema pallidum. Infection and Immunity 57, 3403-3411.

Johnson, R. C., Walby, J., Henry, R. A. \& Auran, N. E. (1973). Cultivation of parasitic leptospires: effect of pyruvate. Applied Microbiology 26, 118-119.

Joys, T. M. (1985). The covalent structure of the phase-1 flagellar filament protein of Salmonella typhimurium and its comparison with other flagellins. Journal of Biological Chemistry 260, 15758-15761.
Kelson, J. S., Adler, B., Chapman, A. J. \& Faine, S. (1988). Identification of leptospiral flagellar antigens by gel electrophoresis and immunoblotting. Journal of Medical Microbiology 26, 47-53.

Kuwajima, G., Asaka, J., Fujiwara, T., Fujiwara, T., Node, K. \& KoNDO, E. (1986). Nucleotide sequence of the hag gene encoding flagellin of Escherichia coli. Journal of Bacteriology 168, 14791483

LAEMMLI, U. K. (1970). Cleavage of structural proteins during the assembly of the head of bacteriophage T4. Nature, London 227, $680-685$.

LAVAllie, E. R. \& Stahl, M. L. (1989). Cloning of the flagellin gene from Bacillus subtilis and complementation studies of an in vitroderived deletion mutation. Journal of Bacteriology 171, 3085-3094.

LECHNER, J. (1989). Structure and biosynthesis of prokaryotic glycoproteins. Annual Review of Biochemistry 58, 173-194.

LeFebvre, R: B., Thiermann, A. B. \& Foley, J. (1987). Genetic and antigenic differences of serologically indistinguishable leptospires of serovar hardjo. Journal of Clinical Microbiology 25, 2094-2097.

Maniatis, T., Fritsch, E. F. \& SambrooK, J. (1982). Molecular Cloning: a Laboratory Manual. Cold Spring Harbor, NY: Cold Spring Harbor Laboratory.

Marshall, R. B., Wilton, B. E. \& Robinson, A. J. (1981). Identification of Leptospira serovars by restriction-endonuclease analysis. Journal of Medical Microbiology 14, 163-166.

Martin, J. H. \& SaVAGe, D. C. (1988). Cloning, nucleotide sequence, and taxonomic implications of the flagellin gene of Roseburia cecicola. Journal of Bacteriology 170, 2612-2617.

MiAO, R. \& FieldSTEEL, A. H. (1978). Genetics of Treponema: relationship between Treponema pallidum and five cultivable treponemes. Journal of Bacteriology 133, 101-107.

Pallesen, L. \& Hindersson, P. (1989). Cloning and sequencing of a Treponema pallidum gene encoding a 31.3-kilodalton endoflagellar subunit (FlaB2). Infection and Immunity 57, 2166-2172.

Pleier, E. \& SCHMITT, R. (1989). Identification and sequence analysis of two related flagellin genes in Rhizobium meliloti. Journal of Bacteriology 171, 1467-1475

Segers, R. P. A. M., van der Drift, A., De Nijs, A., Corcione, P., VAN DER ZeIJST, B. A. M. \& GAASTRA, W. (1990). Molecular analysis of a sphingomyelinase $\mathrm{C}$ gene from Leptospira interrogans serovar hardjo. Infection and Immunity 58, 2177-2185.

SmiberT, R. M. (1973). Spirochaetales, a review. CRC Critical Reviews in Microbiology 2, 491-552.

SOUTHERN, E. M. (1975). Detection of specific sequences among DNA fragments separated by gel electrophoresis. Journal of Molecular Biology 98, 503-517.

Tinoco, I., Borer, P. N., Dengler, B., Levine, M. D., Uhlenbeck, O. C., Crothers, D. M. \& Gralla, J. (1973). Improved estimation of secondary structure in ribonucleic acids. Nature, London 246, $40-41$

Vieira, J. \& Messing, J. (1982). The pUC plasmids, an M13mp7derived system for insertion mutagenesis and sequencing with synthetic universal primers. Gene 19, 259-268.

W allich, R., Moter, S. E., Simon, M. M., Ebnet, K., Heiberger, A. \& KRAMER, M. D. (1990). The Borrelia burgdorferi flagellumassociated 41-kilodalton antigen (flagellin): molecular cloning, expression, and amplification of the gene. Infection and Immunity 58, $1711-1719$.

Wieland, F., Gerhard, P. \& Sumper, M. (1985). Halobacterial flagellins are sulfated glycoproteins. Journal of Biological Chemistry 260, 15180-15185.

YamaGuChI, K., Funio, Y. \& INOUYe, M. (1988). A single amino acid determinant of the membrane localization of lipoproteins in $E$. coli. Cell 53, 423-432.

Yanisch-PerRon, C., Vieira, J. \& Messing, J. (1985). Improved M13 phage cloning vectors and host strains: nucleotide sequences of the M13mp18 and pUC19 vectors. Gene 33, 103-119.

Yasuda, P. H., Steigerwalt, A. G., Sulzer, K. R., Kaufmann, A. F., Rogers, F. \& BRenNeR, D. J. (1987). Deoxyribonucleic acid relatedness between serogroups and serovars in the family Leptospiraceae with proposals for seven new Leptospira species. International Journal of Systematic Bacteriology 37, 407-415. 